\title{
Pengaruh Rasio Keuangan dan Harga Saham dengan EPS sebagai Variabel Moderasi pada Perusahaan Manufaktur yang Terdaftar di DES
}

Hikmah Endraswati dan Any Novianti

Fakultas Ekomomi dan Bisis Islam IAIN Salatiga

Email: h_endraswati@yahoo.co.id + any.novianti@yahoo.com

\begin{abstract}
The purpose of this study was to determine the effect of financial ratio and stock price with Earning Per Share (EPS) as a moderating variable on manufacture companies which were listed in the Shariah Securities List. Financial ratio variables were used in this study as Price Earning Ratio (PER), Debt to Equity Ratio (DER), Current Ratio (CR), Net Profit Margin (NPM), and Size. This study based on Signaling Theory.
\end{abstract}

This study used secondary data was obtained from ICMD and companies annual report. The samples of this study were 46 companies which were listed in Shariah Securities List in the period 2007-2013 and the number of observation was 322. Analysis which was used in this study Residual Test because of the existence of multicollinearity.

The results showed that PER, EPS, and Size have positive effect on stock price and PER, DER, CR, NPM, and Size have effect on stock price jointly. Moderation testing showed that the higher EPS, the influence of NPM to stock price is getting stronger. The other variables in this study did not prove were moderated by EPS.

Keywords: Price Earning Ratio, Earning Per Share, Financial Ratio, Shariah Security List

\begin{abstract}
Abstrak
Tujuan penelitian ini adalah untuk mengetahui pengaruh rasio keuangan dan harga saham dengan Earning Per Share(EPS) sebagai variabel moderasi pada perusahaan manufaktur yang terdaftar di Daftar Efek Syariah. Variabel rasio keuangan yang digunakan adalah Price Earning Ratio (PER), Debt to
\end{abstract}


Equity Ratio (DER), Current Ratio (CR), Net Profit Margin (NPM), dan Size.Penelitian ini didasarkan pada Signaling Theory.

Penelitian ini menggunakan data sekunder yang bersumber dari ICMD dan annual report perusahaan. Sampel penelitian ini 46 perusahaan yang terdaftar pada DES dengan periode 2007-2013 dengan jumlah observasi 322.Teknik analisis yang digunakan adalah Uji Residual karena dengan menggunakan Moderated Regression Analysis(MRA) ditemukan adalanya gejala multikolinearitas.

Hasil penelitian menunjukkan bahwa PER, EPS, dan Size berpengaruh positif terhadap harga saham dan PER, DER, CR, NPM, dan Size secara bersamasama berpengaruh pada harga saham. Pengujian moderasi menunjukkan bahwa semakin tinggi EPS maka pengaruh NPM terhadap harga saham semakin kuat. Variabel lain dalam penelitian ini tidak terbukti dimoderasi oleh EPS.

Kata kunci: Rasio Keuangan, Harga Saham, Earning Per Share, Perusahaan Manufaktur, Daftar Efek Syariah

\section{Pendahuluan}

Perkembangan pasar modal syariah di Indonesia ditandai dengan munculnya regulasi tentang Pasar Modal Syariah yaitu: peraturan BAPEPAMLK No. IX. A13 tentang Penerbitan Efek Syariah dan BAPEPAM-LK No. IX. A14 tentang Akad-Akad yang Digunakan Penerbitan Efek Syariah di Pasar Modal. Sejak31 Agustus 2007, Bapepam \& LK menerbitkan aturan No. II. K1 tentang Kriteria dan Penerbitan Daftar Efek Syariah (DES) dan peluncuran DES pertama kali oleh BAPEPAM-LK tanggal 12 September 2007.

Perkembangan pasar modal syariah berdasarkan data Otoritas Jasa Keuangan (OJK) masih relatif jauh tertinggal dibandingkan dengan pasar modal konvensional yang sudah jauh lebih mapan ada di Indonesia. Kinerja saham syariah pada tahun 2014 mengalami penurunan apabila dibandingkan dengan tahun sebelumnya yang tercermin melalui kapitalisasi pasar saham syariah dan indeks saham syariah (OJK, 2015). 


\section{Gambar 1 \\ Perkembangan Pasar Modal Indonesia (2008-2013)}

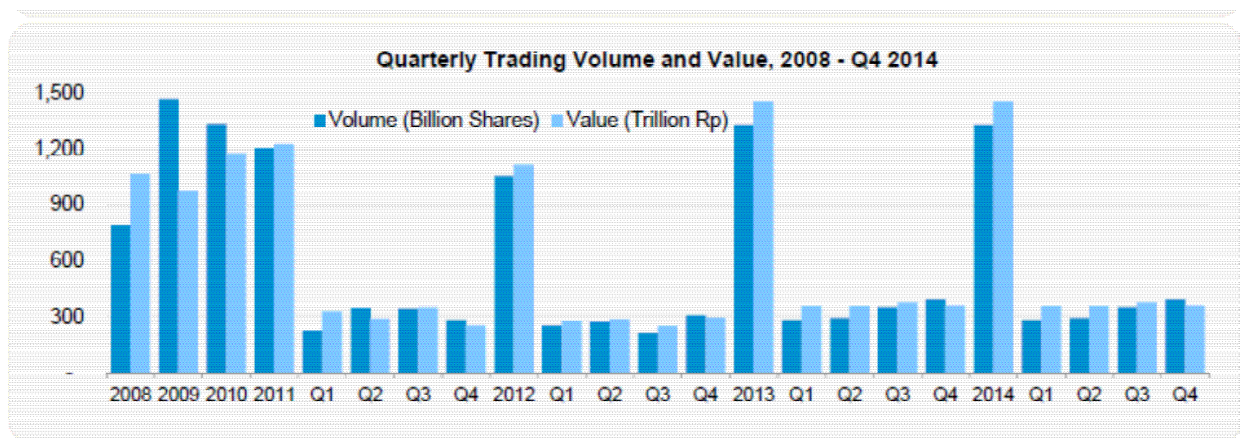

Sumber: Indonesia Capital Market Directory (2014)

\section{Gambar 2}

\section{Perkembangan Saham Syariah Indonesia}

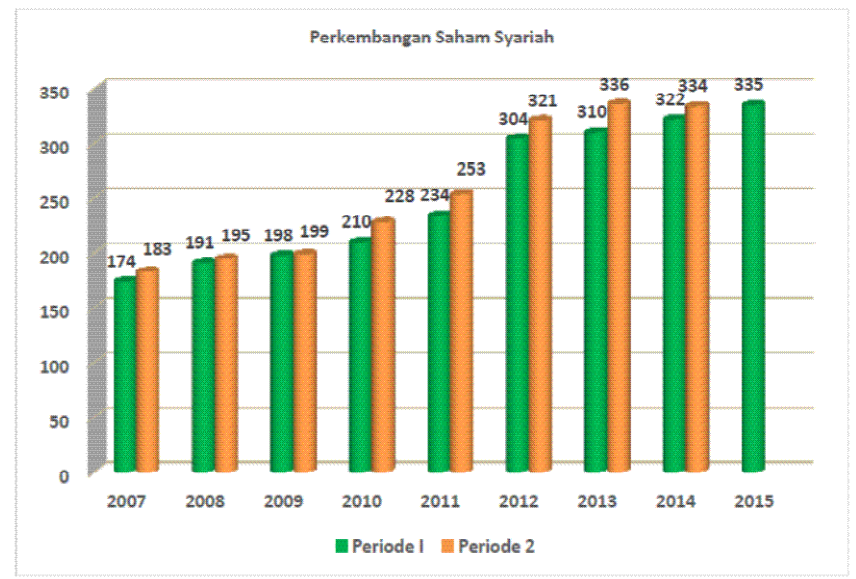

Sumber: OJK (2015)

Perkembangan pasar modal syariah di Indonesia apabila dibandingkan dengan Negara lain seperti Malaysia masih jauh tertinggal apabila dilihat dari jumlah saham dan return saham syariah. Return saham syariah di Malaysia menunjukkan return saham syariah yang positif, dan sebaliknya untuk Indonesia. Indikator lainnya seperti pertumbuhan saham syariah dan kapitalisasi saham syariah mengalami peningkatan yang signifikan. Apabila 
dibandingkan dengan Malaysia, pasar saham syariah dan kapitalisasi saham syariah di Indonesia mengalami peningkatan dan sebaliknya di Malaysia mengalami penurunan pada tahun 2013 (www.icmspecialist.com, 2014).

\section{Gambar 3}

\section{Perkembangan Pasar Modal Syariah di IndonesiaDibandingkan dengan Pasar Modal Syariah di Malaysia}
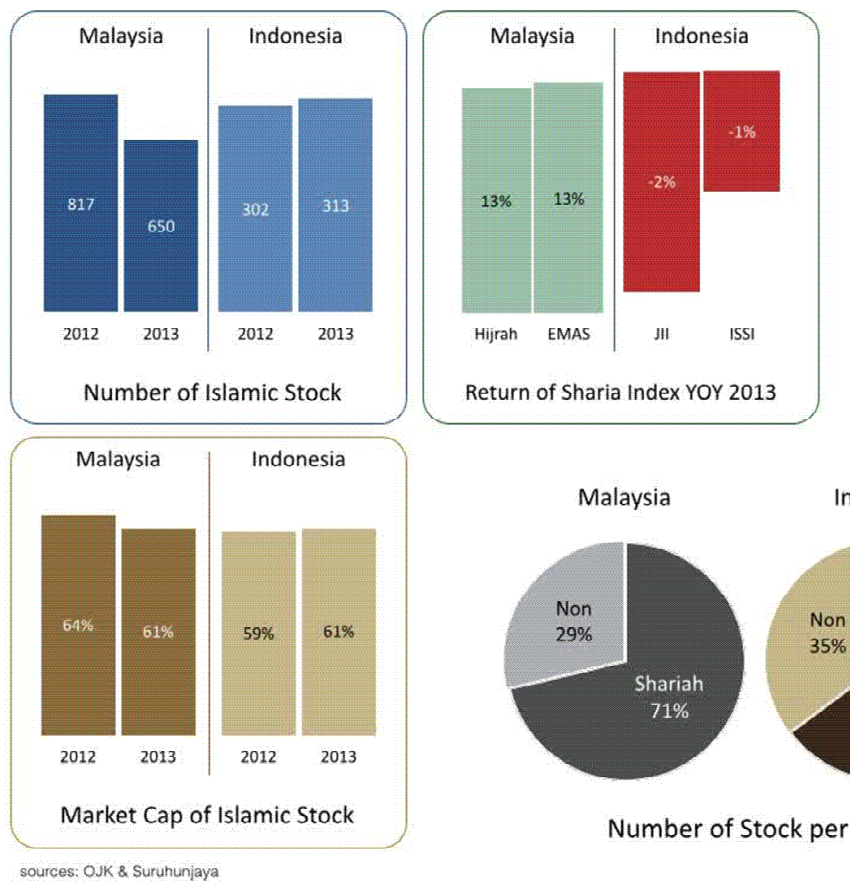

\section{Islamic Stock Performance Malaysia VS Indonesia $2012-2013$ created by icmspecialist.com}

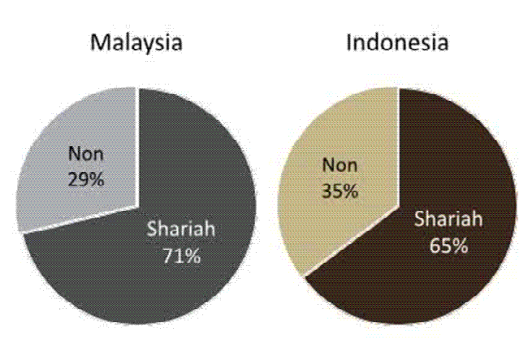

Number of Stock per 2013

Sumber: icmspecialist.com

Hal tersebut menunjukkan bahwa minat investor untuk melakukan investasi pada pasar modal syariah masih terbatas.Faktor yang mempengaruhi minat investor diantaranya adalah kurang pahamnya investor pada pasar modal syariah.Faktor lainnya adalah perkembangan harga saham pada pasar modal syariah turut mempengaruhi minat investor dalam melakukan investasi. Investor yang rasional adalah investor yang menginginkan laba pada investasinya dengan melihat harga saham sebagai salah satu komponen return saham selain dividend (Jogiyanto, 2009; Komala dan Nugroho, 2013). 
Penelitian tentang harga saham di Indonesia dan di berbagai Negara telah banyak dilakukan oleh peneliti sebelumnya seperti Komala dan Nugroho (2013), Nguyen dan Schubler (2013), Abasari et al. (2013), Kose (2011), George dan Hwang (2009), dan Dhaliwal, Heitzman dan Zhen (2006). Ringkasan hasil penelitian pengaruh rasio keuangan terhadap harga saham disajikan pada Tabel 1 berikut ini.

\section{Tabel 1}

Ringkasan Penelitian Pengaruh Rasio Keuangan terhadap Harga Saham

\begin{tabular}{|c|c|c|c|}
\hline Variabel & $\begin{array}{c}\text { Peneliti } \\
\end{array}$ & Lokasi & IIasil \\
\hline Current Ratio & $\begin{array}{l}\text { Guris dan Pala (2014) } \\
\text { Komala dan Nugroho (2013) } \\
\text { Estuari (2010) } \\
\text { Raza Sr II (2010) } \\
\text { Indriana dan Anik (2008) }\end{array}$ & $\begin{array}{l}\text { I'urkey } \\
\text { Indonesia } \\
\text { Indonesia } \\
\text { Pakistan } \\
\text { Indonesia }\end{array}$ & $\begin{array}{l}\text { Berpengaruh } \\
\text { 'lidak berpengaruh } \\
\text { Tidak berpengaruh } \\
\text { Berpengaruh positif } \\
\text { Tidak berpengaruh } \\
\end{array}$ \\
\hline Debt to Liquity Ratio & $\begin{array}{l}\text { Nguyen dan Schubler (2013) } \\
\text { Komala dan Nugroho (2013) } \\
\text { Abasari et al. (2013) } \\
\text { Kose (2011) } \\
\text { Estuari (2010) } \\
\text { Gcorgc dan Hwang (2009) } \\
\text { Indriana dan Anik (2008) } \\
\text { Dhaliwal, Heitzman, dan } \\
\text { /hen (20)6) } \\
\text { Hovakimian et al (2004) } \\
\text { Dhatt dan Kim (1999) }\end{array}$ & $\begin{array}{l}\text { Jerman dan } \\
\text { UK } \\
\text { Indonesia } \\
\text { Indonesia } \\
\text { US } \\
\text { Indoncsia } \\
\text { US } \\
\text { Indoncsia } \\
\text { US } \\
\text { Indonesia } \\
\text { Korea }\end{array}$ & $\begin{array}{l}\text { Berpengaruh negatif } \\
\text { Tidak berpengaruh } \\
\text { Tidak berpengaruh } \\
\text { Berpengaruh negatif } \\
\text { Tidak berpengaruh } \\
\text { Bcrpengaruh ncgatif } \\
\text { Tidak berpengaruh } \\
\text { Berpengaruh Positif } \\
\text { l'idak berpengaruh } \\
\text { Berpengaruh Positif }\end{array}$ \\
\hline Nct Profit Margin & $\begin{array}{l}\text { Absari ct al (2013) } \\
\text { Susyanti dan Misdiyono () } \\
\text { Hatta dan I)wiyanto (2012) } \\
\text { Dita dan Murtaqi (2014) } \\
\text { Hutarauk, Mintarti dan } \\
\text { Parminto (2014) }\end{array}$ & $\begin{array}{l}\text { Indoncsia } \\
\text { Indonesia } \\
\text { Indonesia } \\
\text { Indonesia } \\
\text { Indonesia }\end{array}$ & $\begin{array}{l}\text { Tidak berpengaruh } \\
\text { Tidak berpengaruh } \\
\text { Berpengaruh negatif } \\
\text { Berpengaruh positif } \\
\text { Berpengaruh positif }\end{array}$ \\
\hline Price Earning Ratio & $\begin{array}{l}\text { Guris dan Pala (2014) } \\
\text { Hatta dan Iwiyanto (2012) } \\
\text { Hutarauk, Mintarti dan } \\
\text { Parminto (2014) }\end{array}$ & $\begin{array}{l}\text { Turkey } \\
\text { Indonesia } \\
\text { Indonesia }\end{array}$ & $\begin{array}{l}\text { Berpengaruh } \\
\text { Berpengaruh positif } \\
\text { Berpengaruh negatif }\end{array}$ \\
\hline
\end{tabular}

Sumber: Jurnal diolah

Hasil penelitian tersebut menunjukkan adanya inkonsistensi hasil. Inkonsistensi hasil penelitian tersebut membuka peluang untuk dilakukan penelitian kembali dengan data, metode, atau teori yang berbeda. Adanya inkonsistensi hasil penelitian membuat peneliti menduga ada variabel yang 
dapat memperkuat atau memperlemah (pemoderasi) pengaruh rasio keuangan terhadap harga saham. EPS digunakan sebagai variabel pemoderasi pengaruh rasio keuangan terhadap harga saham didasarkan pada Signaling Theory dan hasil penelitian sebelumnya pengaruh EPS terhadap harga saham yang telah dilakukan oleh Menike dan Prabath (2014) di Srilanka, Mgbame dan Ikhatua (2013) di Nigeria, Menaje (2012) di Pilipina, Sheetaraman dan Raj (2011) di Malaysia, Perera dan Thrikawala (2010) di Srilanka, dan Zhu (2003) di China. Mereka menemukan EPS berpengaruh positif terhadap harga saham dan return saham.

Perbedaan penelitian ini dengan penelitian yang sudah ada tentang harga saham di Indonesia dan di Negara lainnya adalah pertama, variabel EPS sebagai variabel pemoderasi pengaruh rasio keuangan terhadap harga saham. Perbedaan kedua, penelitian dilakukan pada perusahaan manufaktur yang terdaftar pada Daftar Efek Syariah. Perbedaan ketiga, penelitian ini dilakukan dengan periode waktu cukup panjang yaitu selama 7 tahun (20072013) sehingga termasuk dalam longitudinal study. Periode 2007 digunakan setelah muncul DES pertama kali di Indonesia sedangkan penelitian lainnya menggunakan periode waktu yang lebih pendek. Hal ini digunakan untuk mendapatkan gambaran yang lebih general dan lebih nyata berkaitan dengan penelitian ini.

\section{Teori dan Telaah Penelitian Sebelumnya}

Variabel EPS sebagai variabel pemoderasi didasarkan pada Signaling Theory dan hasil penelitian sebelumnya pengaruh EPS terhadap harga saham. Signaling Theory yang dikemukakan oleh Spence (1973) menyatakan bahwa perusahaan yang baik dapat membedakan dirinya dengan perusahaan yang buruk dengan memberikan sinyal tentang kualitasnya pada pasar modal. Sinyal yang kredibel terjadi hanya jika perusahaan yang buruk tidak dapat memberikan sinyal informasi seperti perusahaan yang baik.

Menurut Connelly, Certo, Ireland, dan Reutzel (2011) signaling theory berguna untuk menggambarkan perilaku dua pihak yang memiliki informasi yang berbeda. The sender memilih bagaimana mengkomunikasikan informasi dan the receiver bagaimana mengintepretasikan sinyal informasi. 
Fabozzi (1999) menyatakan bahwa ada dua pendekatan yang dilakukan dalam melakukan analisis sekuritas yaitu analisis fundamental dan analisis teknikal. Analisis fundamental didasarkan pada dua model yaitu: multiplier earning dan asset values. Analisis fundamental lebih sering menggunakan rasio keuangan dan rasio pasar. Analisis teknikal lebih fokus pada perubahan volume dan harga pasar saham.

Penelitian ini tentang harga saham pada perusahaan manufaktur yang terdaftar di DES, sehingga dalam hal ini rasio keuangan perusahaan dapat memberikan sinyal kepada investor tentang kondisi perusahaan.Investor memperhatikan faktor fundamental perusahaan melalui informasi rasio keuangan yang ada pada laporan keuangan sehingga mempengaruhi harga saham perusahaan.Informasi positif pada rasio keuangan perusahaan memberikan sinyal positif pada investor, sehingga investor tertarik untuk melakukan investasi pada perusahaan tersebut, yang selanjutnya mendorong pada peningkatan harga saham perusahaan. Hal yang sebaliknya terjadi ketika informasi mengenai rasio keuangan menujukkan sinyal negatif pada investor, maka investor akan menjual saham atau tidak akan tertarik membeli saham perusahaan karena harga saham mengalami penurunan.

Rasio EPS dapat memperkuat atau memperlemah pengaruh faktor fundamental perusahaan melalui rasio keuangan pada harga saham. Berdasarkan hasil penelitian sebelumnya ditemukan bahwa EPS berpengaruh positif terhadap harga saham. Rasio EPS memberikan sinyal pada investor tentang kondisi profitabilitas pada tiap lembar saham.

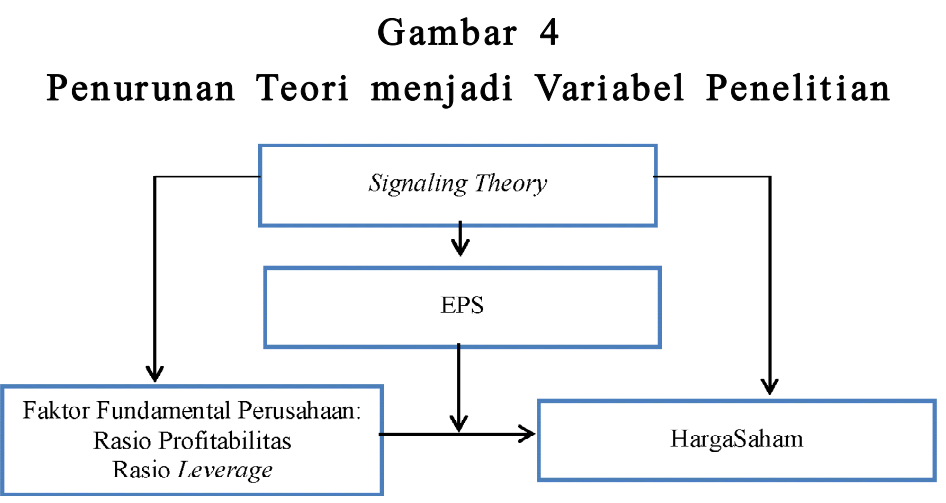

Sumber: Jurnal diolah 
Berdasarkan signaling theory dan hasil penelitian sebelumnya, maka rumusan hipotesis dalam penelitian ini adalah:

$\mathrm{H}_{1 \mathrm{a}}$ : Current Ratio (CR)berpengaruh positif pada harga saham.

$\mathrm{H}_{1 \mathrm{~b}}$ : Earning Per (EPS) Share memoderasi pengaruh Current Ratio (CR) pada harga saham.

$\mathrm{H}_{2 \mathrm{a}}$ : Debt to Equity (DER) berpengaruh negatif pada harga saham.

$\mathrm{H}_{2 \mathrm{~b}}$ : Earning Per Share memoderasi pengaruh Debt to Equity (DER) pada harga saham.

$\mathrm{H}_{3 \mathrm{a}}$ : Net Profit Margin (NPM) berpengaruh positif pada harga saham.

$\mathrm{H}_{3 \mathrm{~b}}$ : Earning Per Share memoderasi pengaruh Net Profit Margin (NPM) pada harga saham.

$\mathrm{H}_{4 \mathrm{a}}$ : Price Earning Ratio (PER) berpengaruh positif pada harga saham.

$\mathrm{H}_{4 \mathrm{~b}}$ : Earning Per Share memoderasi pengaruh Price Earning Ratio (PER) pada harga saham.

\section{Data Penelitian}

Data yang digunakan dalam penelitian ini adalah data sekunder. Data tersebut merupakan data perusahaan yang bergerak dibidang manufaktur yang tergabung dalam Daftar Efek Syariah tahun 2007-2013. Data diambil dari Indonesian Capital Market Directory (ICMD) dan annual report perusahaan yang diperoleh dari www.idx.co.id.

Populasi yang digunakan adalah seluruh perusahaan manufaktur yag tergabung dalam Daftar Efek Syariah (DES) tahun 2007-2013. Teknik pengambilan sampel menggunakan teknik purposive sampling, di mana pemilihan perusahaan dengan menggunakan kriteria-kriteria tertentu. Kriteria sampel yang perusahaan yang harus dipenuhi:

a. Perusahaan yang go publik dalam kurun waktu penelitian tahun 20072013.

b. Perusahaan yang memiliki rasio keuangan yang dibutuhkan dalam penelitian.

c. Perusahaan tidak termasuk dalam data outliers. 
Tabel 2

Pemilihan Sampel Perusahaan Berdasarkan Kriteria

\begin{tabular}{|c|c|}
\hline Kriteria & Jumlah \\
\hline $\begin{array}{l}\text { Populasi perusahaaan manufaktur yang terdaftar pada DLS tahun } \\
2007-2013\end{array}$ & 164 \\
\hline $\begin{array}{l}\text { Perusahaan yang tidak go publik dalam kurun waktu penelitian } \\
\text { tahun } 2007-2013 \text { dalam DLS. }\end{array}$ & 92 \\
\hline $\begin{array}{l}\text { Pcrusahaan yang tidak momiliki rasio dan faktor-faktor } \\
\text { penghitungan rasio yang digunakan dalam penelitian ini }\end{array}$ & 7 \\
\hline l'erusahaan yang memiliki data outliers & 19 \\
\hline Jumlah perusahaan & 46 \\
\hline Jumlah observasi penelitian $46 \times 7$ & 322 \\
\hline
\end{tabular}

Sumber: Hasil pengolahan data dari DES tahun 2007-2013

\section{Definisi Operasional dan Pengukuran Variabel}

\section{Variabel Dependen}

Variabel dependen yang digunakan adalah harga saham pada perusahaan manufaktur yang terdaftar dalam Daftar Efek Syariah tahun 2007-2012. Harga saham yang digunakan dalam penelitian ini adalah harga saham penutupan (closing price). Pengukuran harga saham dengan closing price telah digunakan oleh:Guris dan Pala (2014), Komala dan Nugroho (2013), Estuari (2010), Raza Sr H (2010), Indriana dan Anik (2008), Menike dan Prabath (2014), Mgbame dan Ikhatua (2013), Menaje (2012), Sheetaraman dan Raj (2011), Perera dan Thrikawala (2010), dan Zhu (2003).

Harga saham $=$ Closing Price

\section{Variabel Moderasi}

Variabel moderasidalam penelitian ini adalah Earning per Share (EPS). Menurut Fabozzi (1999) EPS merupakan rasio yang menggambarkan besarnya pengembalian modal untuk setiap satu lembar saham. EPS merupakan profitabilitas perusahaan yang tergambar dalam setiap lembar saham. Pengukuran EPS dalam penelitian ini telah digunakan oleh: Menike 
dan Prabath (2014), Mgbame dan Ikhatua (2013), Menaje (2012), Sheetaraman dan Raj (2011), Perera dan Thrikawala (2010), dan Zhu (2003).Rumus dari Earning Per Share yaitu:

$$
\mathrm{EPS}=\frac{\text { Laba Bersih Setelah Pajak }}{\text { Jumlah Saham Beredar }}
$$

\section{Variabel Independen}

a. Current Ratio (CR)

Menurut Fabozzi (1999) CR merupakan perbandingan antara aktiva lancar (current asset) dengan hutang lancar (current liabilities). Pengukuran rasio CR dalam penelitian ini telah digunakan oleh Guris dan Pala (2014), Komala dan Nugroho (2013), Estuari (2010), Raza Sr H (2010), Indriana dan Anik (2008)dan dirumuskan sebagai berikut:

$$
C R=\frac{\text { currentasset }}{\text { currentliabilities }}
$$

b. Debt to Equity Ratio (DER)

Menurut Fabozzi (1999)Debt to Equity Ratio (DER) merupakan kemampuan dari perusahaan untuk memenuhi kewajibannya yang ditujukan dengan beberapa bagian dari modal sendiri yang digunakan untuk membayar hutang.Pengukuran DER dalam penelitian ini telah digunakan oleh: Nguyen dan Schubler (2013), Komala dan Nugroho (2013), Abasari et al. (2013), Kose (2011), Estuari (2010), George dan Hwang (2009), Indriana dan Anik (2008), Dhaliwal, Heitzman, dan Zhen (2006), Hovakimian et al. (2004), dan Dhatt dan Kim (1999). Rumus dari DER adalah sebagai berikut:

$$
D E R=\frac{\text { TotalHutang }}{\text { TotalModalSendiri }}
$$

c. Net Profit Margin (NPM)

Menurut Fabozzi (1999) Net Profit Margin (NPM) merupakan rasio yang menggambarkan besarnya laba bersih yang diperoleh perusahaan. 
Pengukuran NPM telah digunakan oleh Abasari et al. (2013), Susyanti dan Misdiyono (2013), Hatta dan Dwiyanto (2012), Dita dan Murtaqi (2014), dan Hutarauk, Mintarti dan Parminto (2014). Rumus dari Net Profit Margin(NPM) adalah sebagai berikut:

$$
N P M=\frac{\text { Laba Bersih }}{\text { Penjualan }}
$$

d. Price Earning Ratio (PER)

Menurut Fabozzi (1999) Price Earning Ratio (PER) merupakan perbandingan antara harga saham di pasar dengan pendapatan yang diterima. Pengukuran variabel ini telah digunakan oleh Guris dan Pala (2014), Hatta dan Dwiyanto (2012), dan Hutarauk, Mintarti dan Parminto (2014). Rumus dari rasio ini adalah:

$$
\text { PER }=\frac{\text { HargaPasarSaham }}{\text { EarningPerShare }}
$$

\section{Variabel Kontrol}

Penelitian ini menggunakan variabel kontrol Size. PengukuranSize dalam penelitian ini adalah total aset.Menurut Fabozzi (1999) total aset mampu menggambarkan apa yang dimiliki oleh perusahaan sehingga dapat menjelaskan seberapa besar perusahaan berdasarkan aset yang dimiliki. Pengukuran ini telah digunakan oleh peneliti sebelumnya seperti Endraswati, Suhardjanto, dan Krismiaji (2012).

$$
\text { Size }=\text { Total Aset }=\text { Aset Lancar }+ \text { Aset Tetap }
$$

\section{Hasil dan Pembahasan}

\section{Statistik Deskriptif}

Statistik deskriptif memberikan gambaran umum tentang objek penelitian yang dijadikan sampel penelitian. 
Tabel 5

Statistik Deskriptif

\begin{tabular}{cccccc}
\hline \hline Variabel & $\mathrm{N}$ & Minimum & Maksimum & Mean & Std. Deviasi \\
\hline CR & 322 & 0.22 & 12.23 & 2.6531 & 1.92421 \\
TER & 322 & 0.08 & 2.70 & 0.6941 & 0.49356 \\
NPM & 322 & 0.01 & 3.95 & 0.1379 & 0.23599 \\
PER & 322 & 1.89 & 87.69 & 15.6085 & 12.62253 \\
EPS & 322 & 1.00 & 4300.00 & $2.8094 \mathrm{E} 2$ & 460.61588 \\
Size & 322 & $4.65 \mathrm{E} 10$ & $3.08 \mathrm{E} 13$ & $3.5302 \mathrm{E} 12$ & $4.85709 \mathrm{E} 12$ \\
IIGS & .322 & 50.00 & 31000.00 & $3.6109 \mathrm{~F}, 3$ & 6052.82425 \\
\hline \hline
\end{tabular}

Sumber: Hasil Olah Data

Berdasarkan Tabel 5 dapat diketahui bahwa nilai harga saham (HGS) terendah adalah Rp. 50. Hal ini menunjukan bahwa perusahaan manufaktur yang terdaftar dalam DES pada periode tahun 2007-2013 memiliki harga saham yang sangat rendah. Hal ini dapat disebabkan oleh pada periode tahun 2007-2013 sempat terjadi krisis finansial dunia yang berdampak pada harga saham perusahaan manufaktur tertentu. Hal tersebut dapat terjadi pada perusahaan dengan bahan baku impor atau perusahaan dengan mayoritas pangsa pasarnya adalah luar negeri. Perusahaan-perusahaan yang melakukan kegiatan perdagangan internasional memiliki dampak terbesar pada saat terjadi krisis finansial dunia (Nezky, 2013).

Harga saham tertinggi sebesar Rp. 31.000 hal ini menunjukan bahwa perusahaan telah tumbuh dan berkembang dengan sangat baik meskipun sedang terjadi krisis finansial dunia. Rata-rata harga saham Rp. 3.610 dengan standar deviasi sebesar Rp. 6052. Rata-rata harga saham masih cukup baik hal ini menunjukkan bahwa krisis finansial dunia tidak terlalu berpengaruh besar pada perusahaan manufaktur yang terdaftar di DES.

Berdasarkan pada Tabel 5 tersebut nilai terendah CR adalah 0,22 artinya ada perusahaan yang dianggap kurang mampu dalam memenuhi kewajiban jangka pendeknya, dengan nilai aktiva lancar yang lebih kecil dari kewajiban jangka pendeknya. Kemungkinan hal tersebut terjadi karena suatu perusahaan dalam industri manufaktur terkena dampak krisis finansial dunia. Nilai tertinggi CR adalah 12,23 hal ini menunjukan bahwa perusahaan dianggap memiliki aktiva lancar yang lebih sehingga mampu memenuhi 
kewajiban jangka pendeknya. Rata-rata nilai CR adalah 2,6531 hal ini menunjukan kepada investor bahwa perusahaan manufaktur di Indonesia yang terdaftar pada DES mampu memenuhi kewajiban jangka pendeknya.

BerdasarkanTabel 5 nilai DER memiliki nilai terendah 0,08. Hal ini menunjukan bahwa kemampuan perusahaan dalam menghasilkan profitabilitas tinggi karena kecilnya hutang yang dimiliki oleh perusahaan. Nilai DER tertinggi 2,70. Hal ini menggambarkan bahwa semakin besar hutang yang dimiliki oleh perusahaan akan mengakibatkan berkurangnya profitabilitas, karena dengan DER yang terlalu tinggi maka keuntungan semakin berkurang karena semakin besar perusahaan dalam membayar hutangnya. Rata-rata DER adalah 0,6941dengan standar deviasi 0,49356.

Tabel 5 menunjukan nilai terendah NPM adalah 0,01 artinya dengan nilai NPM 0,01 kinerja perusahaan kurang baik karena perusahaan tidak mampu memberikan keuntungan bagi investor. Nilai tertinggi NPM adalah 3,95. Hal ini menunjukan kinerja perusahaan semakin baik karena perusahaan mampu menghasilkan keuntungan untuk para investor. Rata-rata NPM sebesar 0,1379 dengan standar deviasi 0,23599.

Berdasarkan dari tabel 5 nilai terendah dari PER sebesar 1,89 menunjukan bahwa prestasi perusahaan di masa depan rendah, karena PER menggambarkan kinerja perusahaan. PER merupakan perbandingan dari harga saham dengan laba yang diperoleh perusahaan. Rendahnya PER yang mempengaruhi harga saham juga dapat dikarenakan krisis ekonomi yang terjadi pada periode waktu yang digunakan dalam penelitian ini. Nilai tertinggi PER 87,69 menunjukan bahwa perusahaan telah tumbuh dan berkembang dengan baik dan diharapkan dapat terus berkembang dimasa yang akan datang. Rata-rata dari PER adalah 15,6085 dan standar deviasi 12,62253 .

Nilai terendah EPS berdasarkan tabel 5 adalah sebesar 1, hal ini menunjukan bahwa terjadi penurunan keuntungan bersih untuk pengembalian modal untuk setiap satu lembar saham. Nilai tertinggi dari EPS adalah sebesar 4300 di mana hal ini menggambarkan telah terjadi peningkatan keuntungan bersih pada perusahaan karena terjadi peningkatan dalam pengembalian modal untuk setiap satu lembar saham. Rata-rata EPS adalah 2809 dengan standar deviasi 46061. 
Variabel kontrol dalam penelitian ini adalah SIZE, dengan nilai terendah berdasarkan tabel 5 adalah Rp. 46.469.000.000. Hal ini menggambarkan bahwa total asset dari suatu perusahaan masih rendah, padahal total asset digunakan untuk menghasilkan pendapatan perusahaan. Hal ini berarti total asset yang rendah akan menghasilkan pendapatan yang rendah pula. Nilai tertinggi dari SIZE adalah Rp. 30.792.884.000.000. Hal ini menunjukkan bahwa ketika total asset perusahaan naik, maka pendapatan meningkat karena perusahaan memiliki sumber daya yang besar untuk menghasilkan pendapatan tersebut. Hal ini dapat diartikan bahwa dengan total asset yang tinggi maka pencapaian pendapatan perusahaan juga akan tinggi. Rata-rata size (total asset) dalam penelitian ini adalah Rp. 3.530.195.596.273,29 dengan standar deviasi Rp. 4.857.090.430.246,57.

\section{Pengujian Hipotesis}

Pengujian hipotesis dilakukan setelah peneliti melakukan uji asumsi klasik. Pada tahap selanjutnya peneliti melakukan pengujian hipotesis pengaruh variabel independen terhadap variabel dependen dengan menggunakan analisis regresi berganda. Hasil pengujian ada pada tabel berikut ini:

Tabel 6

Hasil Uji Regresi

\begin{tabular}{llll}
\hline Variabel & Koefisien & Nilai t & Sig \\
\hline (Constant) & -0.723 & -1.448 & \\
CR & 0.026 & 1.266 & 0.207 \\
DER & 0.001 & -0.018 & 0.985 \\
NPM & -0.006 & -0.323 & 0.747 \\
PTR & 0.407 & 24.738 & $\left.0.000^{* * *}\right)$ \\
EPS & 0.985 & 51.317 & $\left.0.000^{* * *}\right)$ \\
SIZE & 0.044 & 2.497 & $\left.0.013^{* *}\right)$ \\
Nilai F & 835.454 & & $\left.0.000^{* * *}\right)$ \\
Adj. $\mathrm{R}^{2}$ & 0.941 & & \\
Durbin Walson & 2.226 & & \\
\hline ***) : sig pada $1 \%$ & & \\
$* *$ : sig pada $5 \%$ & & \\
$*$ *) : sig pada $10 \%$ & &
\end{tabular}

Sumber: Data sekunder yang diolah 
Berdasarakan dari hasil uji $\mathrm{F}$, diperoleh nilai $\mathrm{F}$ sebesar 835,454 dan sig 0,000. lebih kecil dari 0,05. Hal ini menunjukan bahwa variabel CR, DER, NPM, PER, EPS, dan SIZE secara simultan berpengaruh signifikan terhadap harga saham pada perusahaan manufaktur yang terdaftar dalam Daftar Efek Syariah Tahun 2007-2013.

Berdasarkan dari uji parsial di atas, diketahui bahwa CR tidak berpengaruh terhadap harga saham dengan nilai signifikasi 0,207 di mana nilai signifikasi CR lebih besar dari 0,05. Dengan demikian hipotesis pertama $\left(\mathrm{H}_{1 \mathrm{a}}\right)$ tidak didukung dalam penelitian ini. Hal ini dikarenakan investor mungkin beranggapan bahwa $\mathrm{CR}$ yang terlalu tinggi menunjukan manajemen terlalu berhati-hati (tidak menyukai risiko) dalam pengelolaan likuiditas sehingga hasil pengembalian investasi menjadi kecil. Hasil penelitian ini dapat pula disebabkan oleh kondisi ekonomi makro yaitu terjadinya krisis finansial dunia pada tahun penelitian sehingga mayoritas perusahaan manufaktur mengatur likuiditasnya dengan ketat. Krisis finansial dunia berpengaruh pada harga saham dan perdagangan internasional (Nezky, 2013). Hasil penelitian ini mendukung hasil penelitian yang dilakukan oleh Indriana dan Anik (2008) di Indonesia, Estuari (2010) di Indonesia, dan Komala dan Nugroho (2013) di Indonesia. Hasil penelitian ini berbeda dengan hasil penelitian yang dilakukan oleh Raza (2010) di Pakistan dan Guris dan Pala (2014) di Turkey.

Hasil penelitian ini menunjukkan bahwa DER tidak berpengaruh terhadap harga saham dengan nilai signifikasi 0,985 yang lebih besar dari 0,05 . Hal ini dapat disebabkan oleh rata-rata nilai DER pada periode penelitian ini tidak terlalu tinggi sehingga tidak berpengaruh signifikan pada harga saham. Rata-rata nilai DER 0,6 dalam periode penelitian ini dapat dilatar belakangi oleh kondisi ekonomi makro yang sedang terjadi (terjadi krisis finansial dunia), sehingga mayoritas perusahaan berhati-hati dalam pengelolaan hutangnya. Dengan demikian hipotesis kedua $\left(\mathrm{H}_{2 \mathrm{a}}\right)$ tidak didukung dalam penelitian ini. Hasil penelitian ini mendukung hasil penelitian yang dilakukan oleh Hovakimian et al. (2004) di Indonesia, Indriana dan Anik (2008) di Indonesia, Estuari (2010) di Indonesia, Abasari et al. (2013) di Indonesia, dan Komala dan Nugroho (2013) di Indonesia. Hasil penelitian ini berbeda dengan Dhatt dan Kim (1999) di Korea, Dhaliwal, Heitzman 
dan Zhen (2006) di US, George dan Hwang (2009) di US, Kose (2011) di US, Nguyen dan Schubler (2013) di Jerman dan UK.

Penelitian ini menunjukan bahwa NPM tidak berpengaruh terhadap harga saham dengan nilai signifikasi 0,747 lebih besar dari 0,05. Dengan demikian hipotesis ketiga $\left(\mathrm{H}_{3 \mathrm{a}}\right)$ tidak didukung dalam penelitian ini. NPM tidak signifikan terhadap harga saham kemungkinan terjadi karena nilai ratarata NPM pada periode penelitian ini hanya 0,13 . Nilai NPM yang rendah kemungkinan karena pada periode penelitian terjadi krisis finansial dunia sehingga mempengaruhi rasio NPM, di mana dengan adanya krisis finansial dunia mempengaruhi nilai ekspor Indonesia secara umum (Nezky, 2013).Hasil penelitian ini mendukung hasil penelitian yang dilakukan oleh Absari et al. (2013) di Indonesia dan Susyanti dan Misdiyono (2013) di Indonesia. Hasil penelitian ini berbeda dengan hasil penelitian yang dilakukan oleh Hatta dan Dwiyanto (2012) di Indonesia, Ditta dan Murtaqi (2014) di Indonesia, Hutarauk, Mintarti dan Parminto (2014) di Indonesia.

Berdasarakan hasil pengujian diatas, PER berpengaruh positif terhadap harga saham, dengan nilai signifikasi 0,000 yang lebih kecil dari 0,05. Dengan demikian hipotesis keempat $\left(\mathrm{H}_{4 \mathrm{a}}\right)$ diterima. PER yang signifikan dapat menjelaskan bahwa investor beranggapan prestasi perusahaan dimasa yang akan datang cukup tinggi dengan laba perusahaan yang meningkat dimasa yang akan datang. Hasil penelitian ini mendukung hasil penelitian yang dilakukan oleh Hatta dan Dwiyanto (2012) di Indonesia dan Guris dan Pala (2014) di Turkey. Hasil penelitian ini berbeda dengan hasil penelitian yang dilakukan oleh Hutauruk, Mintarti, dan Parminto (2014) di Indonesia.

Dari hasil uji secara parsial EPS berpengaruh positif terhadap harga saham, dengan nilai signifikasi 0,000 lebih kecil dari 0,05. Hal ini dapat disebabkan oleh EPS merupakan salah satu indikator yang dapat menunjukan kinerja perusahaan. Besar kecilnya EPS ditentukan oleh besarnya laba perusahaan. Hasil penelitian ini mendukung hasil penelitian yang dilakukan olehMenike dan Prabath (2014) di Srilanka, Mgbame dan Ikhatua (2013) di Nigeria, Menaje (2012) di Pilipina, Sheetaraman dan Raj (2011) di Malaysia, Perera dan Thrikawala (2010) di Srilanka, dan Zhu (2003) di China. Mereka menemukan EPS berpengaruh positif terhadap harga saham dan return saham. 
SIZE berpengaruh positif terhadap harga saham, dengan nilai singifikasi 0,013 di mana nilai ini lebih kecil dari 0,05. Dengan demikian variabel kontrol dalam penelitian ini berpengaruh terhadap harga saham.Kemungkinan investor menganggap bahwa ukuran perusahaan yang besar menunjukan perusahaan tersebut telah mencapai kemapanan sehingga semakin besar perusahaan maka semakin besar kemampuan perusahaan untuk meningkatkan profitabilitasnya sehingga meningkatkan harga sahamnya. Hasil penelitian ini mendukung hasil penelitian yang dilakukan oleh Banz dan Reinganum (1981) di US, Blume dan Stambaugh (1983) di US, dan Anuradha (2007) di Sri Lanka. Hasil penelitian ini berbeda dengan Shafana, Rimziya, dan Jariya (2013) di Colombo.

Pengujian hipotesis moderasi dalam penelitian ini menggunakan uji residual karena adanya multikolinearitas pada variabel yang diinteraksikan. Hasil pengujian residual ada pada Tabel 7 di bawah ini.

Tabel 7

Hasil Uji Moderasi

\begin{tabular}{cccc}
\hline Variabel & Koefisien & Nilai t & Signifikasi \\
\hline CR & 0.024 & 0.427 & 0.670 \\
DFR & 0.004 & 0.067 & 0.946 \\
NPM & 0.128 & 2.301 & $\left.0.022^{* *}\right)$ \\
PFR & 0.070 & 1.258 & 0.209 \\
\hline
\end{tabular}

$* * *)$ : sig pada $1 \%$

**) : sig pada $5 \%$

*) : sig pada $10 \%$

Sumber: Data sekunder diolah

Pada tabel 7 diketahui bahwa CR memiliki nilai signifikansi sebesar 0,670 di mana nilai tersebut lebih besar dari 0,05, sehingga dikatakan bahwa EPS tidak memoderasi pengaruh $\mathrm{CR}$ pada harga saham. Hal ini berarti $\mathrm{H}_{1 \mathrm{~b}}$ tidak didukung pada penelitian ini. Dengan demikian dapat diartikan bahwa EPS tidak dapat memperlemah harga saham pada saat CR rendah, dan EPS tidak dapat memperkuat harga saham disaat CR tinggi. 
Nilai signifikasi DER sebesar 0,946, di mana nilai tersebut lebih besar dari 0,05. Artinya bahwa EPS tidak memoderasi pengaruh DER terhadap harga saham. Hal ini berarti $\mathrm{H}_{2 b}$ tidak didukung pada penelitian ini. Hal ini diartikan bahwa EPS tidak dapat memperkuat harga saham di saat DER tinggi dan EPS tidak dapat memperlemah harga saham disaat DER rendah.

Nilai signifikasi NPM sebesar 0,022, di mana nilai tersebut lebih kecil dari 0,05. Artinya EPS memoderasi pengaruh NPM terhadap harga saham. Hal ini berarti $\mathrm{H}_{3 \mathrm{~b}}$ didukung dalam penelitian ini. EPS dalam penelitian ini termasuk quasi moderation. EPS memperlemah harga saham di saat NPM rendah dan memperkuat harga saham disaat NPM tinggi. NPM merupakan rasio profitabilitas yang menggambarkan laba bersih yang diperoleh perusahaan. NPM yang tinggi menunjukkan keuntungan perusahaan yang tinggi. Semakin tinggi EPS maka minat investor untuk investasi akan meningkat, dan hal ini memperkuat pengaruh NPM pada harga saham.

Pada tabel diatas nilai signifikasi PER sebesar 0,209, di mana nilai signifikasi lebih besar dari 0,05. Artinya bahwa EPS tidak memoderasi pengaruh PER terhadap harga saham. Hal ini berarti $\mathrm{H}_{4 \mathrm{~b}}$ tidak didukung pada penelitian ini. Dengan demikian EPS tidak dapat memperkuat harga saham disaat PER tinggi dan EPS tidak dapat memperlemah harga saham disaat PER rendah.

\section{Penutup}

Berdasarkan hasil penelitian tersebut, maka kesimpulan penelitian ini adalah sebagai berikut:

1. PER, EPS, dan SIZE secara parsial berpengaruh terhadap harga saham pada perusahaan manufaktur yang terdaftar di DES. Hal ini menunjukkan bahwa investor untuk melakukan investasi memperhatikan atau mempertimbangkan rasio PER, rasio EPS, dan SIZE perusahaan yang diukur dengan total asset secara parsial.

2. Secara simultan semua variabel CR, DER, NPM, PER, EPS dan SIZE berpengaruh terhadap harga saham. Artinya investor memperhatikan secara bersama-sama semua rasio keuangan yang digunakan dalam penelitian ini ketika melakukan investasi. 
3. EPS memoderasi pengaruh NPM terhadap harga saham. Hal ini menunjukkan bahwa semakin tinggi EPS, maka pengaruh NPM terhadap harga saham semakin kuat. Artinya investor memperhatikan rasio EPS dan NPM ketika melakukan investasi.

4. Peneliti menyarankan untuk penelitian yang akan datang dapat menggunakan teori yang berbeda seperti teori Agensi, selain itu dapat menggunakan metodologi yang berbeda misalnya penggunaan variabel mediasi, melakukan split sample atau membandingkan antar industri, membandingkan dengan perusahaan lain dalam satu industri pada negara yang berbeda.

\section{Daftar Pustaka}

Absari, Dyatri Utami Arian. Made Sudarma \& Grahita Chandrarin. 2013. "Analisis Pengaruh Faktor Fundamental Perusahaan dan Risiko Sistematis terhadap Return Saham.” Jurnal El-Muhasaba, 3 (2): 129.

Anuradha, PANS. 2007. "Conditional Relation between Beta and Returns: Evidence from Sri Lanka Colombo Stock Exchange." Thesis. University of Colombo.

Banz, RW. 1981. "The Relation between Return and Market Value of Common Stocks." Journal of Financial Economics, 9: 13-18.

Blume, M. \& Stambaugh, R. 1983. "Biases in Computed Returns: an Application to the Size Effect." Journal of Financial Economics, Vol. 12: 387-404.

Connelly, Brian., Certo, S. Travis., Ireland, R. Duane., \& Reutzel, Christopher R. 2011. "Signaling Theory: A Review and Assessment." Journal of Management, Vol. 37 (1): 39-67

Dhatt, M. S., Kim, Y. H., \& Mukerji, S. 1999. "Relations between Stock Returns and Fundamental Variables: Evidence from Segmented Market." Asia Pacific Financial Market, 6: 221-233.

Dhaliwal, D., S. Heitzman., \& Zhen L. O. 2006. "Taxes, Leverage, and the Cost of Equity Capital.” Journal of Accounting Research, 44 (4): 691-723

Dita, Amalia Husna., \&Murtaqi, Ishrochmani. 2014. "The Effect of Net Profit Margin, Price to Book Value and Debt to Equity Ratio to Stock Return in the Indonesian Consumer Goods Industry." Journal of Business and Management, Vol. 3 (3): 305-315. 
Estuari, A. 2010.”Pengaruh Currant Ratio (CR), Debt to Equity Ratio (DER), Return on Investment (ROI), Earning per Share (EPS), dan Dividend Payout Ratio (DPR) terhadap Return Saham Perusahaan di Bursa Efek Indonesia."Thesis. Universitas Diponegoro.

Fabozzi, Frank. 1999. Manajemen Investasi. Salemba Empat. Jakarta.

George T., \& Hwang, C. 2009. "Leverage, Financial Distress, and the Cross Section of Stock Return."Journal of Financial Economics, 96 (1): 56-79

Guris, Selahattin. \& Pala, Aynur. 2014. "Equity Return, Firm-Specific Characteristics and Sector Rotation: Evidence from Turkey. International." Journal of Economics and Financial Issues, Vol. 4 (2): 264-276.

Hatta, Atika Jauharia., \& Dwiyanto, Bambang Sugeng. 2012. "The Company Fundamental Factors and Systematic Risk in Increasing Stock Price." Journal of Economics, Business, and Accountancy Ventura, 15 (2): 245-256.

Hovakimian, Armen., Gayane Hovakimian., \& Hassan Tehranian. 2004. "Determinants of Target Capital Structural the Case of Dual Debt and Equity Issues." Journal of Financial Economics, 71: 517-540.

Hutauruk, Martinus Robert., Mintarti, Sri., \& Parminto, Ardi. 2014. "Influence of Fundamental Ratio, Market Ratio and Business Performance to The Systematic Risk and Their Impacts to the Return on Shares at the Agricultural Sector Companies at the Indonesia Stock Exchange for the Period of 2010-2013.” Academic Research International, Vol. 5 (5): 149-168.

Indriana, TL.,\& Anik Widyani. 2010. "Pengaruh ROA, EPS, Current Ratio, DER, dan Inflasi terhadap Return Saham (Studi Kasus pada Perusahaan Manufaktur di Bursa Efek Indonesia Periode Tahun 2006-2008)."Majalah Ilmiah Fakultas Ekonomi Universitas Semarang, 9 (1).

Jogiyanto.2009. Teori Portofolio dan Analisis Investasi. Edisi Keenam. BPFE.Yogyakarta.

Komala, Lievila Angela Pinkan. \& Nugroho, Paskah Ika. 2013. “The Effect of Profitability ratio, Liquidity, and Debt towards Investment Return," Journal of Business and Economics. Vol. 4(11): 1176-1186.

Kose, E. 2011.”Dissecting the Leverage Effect on Stock Return.” Working Paper. Washington University in St. Louis.

Menaje, P. M., \& Jr. 2012."Impact of Selected Financial Variables on Share Price of Publicly Listed Firms in the Philippines," American International Journal of Contemporary Research, Vol. 2 (9): 98-104. 
Menike, M. G. P. D., \& Prabath, US. 2014. "The Impact of Accounting Variables on Stock Price: Evidence from the Colombo Stock Exchange, Srilanka." International Journal of Business and Management, Vol. 9 (5): 125-138.

Mgbame, C. O., \& Ikhatua, O. J. 2013. "Accounting Information and Stock Volatility in the Nigerian Capital Markets: a Garch Analysis Approach." International Review of Management and Business Research, 2.

Nezky, Mita. 2013. "Pengaruh Krisis Ekonomi Amerika Serikat terhadap Bursa Saham dan Perdagangan Indonesia." Buletin Ekonomi Moneter dan Perbankan, Januari.

Nguyen, Tristan.,\& Schubler, Alexander. 2013. "Leverage, Maturities of Debt and Stock Performance." International Journal of Banking and Finance, Vol. 10 (1): 74-93.

Perera, R. A. A. S., \& Thrikawala, S. S.2010. An Empirical Study of the Relevance of Accounting Informationon Investor's Decision.ICBI. University of Kelaniya, Sri Lanka.

Raza, Sr. 2010.The Impact of Financial Performance of the Company on its Share Price; Evidence from Pakistan Stock Exchange. Pakistan: Research Gate Publication.

Seetharaman, A., \& John Rudolf Raj. 2011. "An Empirical Study on the Impact of Earning Per Share on Stock Price of a Listed Bank in Malaysia." The International Journal of Applied Economics and Finance, 5 (2): 114-126.

Shafana, MACN., Rimziya, Al Fathima., \& Jariya, AM Inun. 2013. "Relationship between Stock Return and Firm Size, and Book to Market Equity: Empirical Evidence from Selected Companies Listed on Milanka Price Index in Colombo Stock Exchange." Journal of Emerging Trends in Economics and Management Sciences, 4(2): 217-225.

Spence, M. 1973. Job Market Signaling. The Quarterly Journal of Economics, 87 (3): 355-374.

Susanti, Dwi., \& Misdiyono. 2012. "Financial Performance Analysis to Stock's Price of the Metal Manufacturing Sector in Indonesia Stock Exchange." Financial Performance Analysis.Universitas Guna Dharma.

Zhu, W. X. 2003. "The Information of Stock Price in response to the Volume of Circulating Common Stocks." China Soft Science, 2: 44-47.

OJK, 2014.Indonesia Capital Market Directory. Jakarta. 
OJK, 2015.Statistik Pasar Modal Syariah. Direktorat Pasar Modal Syariah. Otoritas Jasa Keuangan. Jakarta.

OJK, 2014.Kinerja Pasar Saham Syariah 2013: Malaysia vs Indonesia. www.icmspecialist.com. 